\title{
Physicochemical Analysis of the Water Wells in the Area of Kosovo Energetic Corporation (Obiliq, Kosovo)
}

\author{
Skender Demaku', Naser Bajraktari2* \\ 1 University of Pristine "Hasan Pristina", Faculty of Natural Sciences and Mathematics, Department of Chemistry, \\ "Nëna Tereze" St., 10000, Pristina, Kosovo \\ 2 Faculty of Agroecology and Agroenvironment, University of Peja, "Haxhi Zeka" St., 30000, Pejë, Kosovo \\ * Corresponding author`s e-mail: bajraktari.naser@outlook.com
}

\begin{abstract}
The authors analyzed the physicochemical parameters and heavy metals characterizing the wells at three different sites (nearby villages) in the area of KEC (Kosovo Energetic Corporation). The KEC power plants are the only ones in Kosovo that use fossil-fueled energy (lignite) for the production of the electricity. This process may pollute the environment through the release of airborne aerosols (contaminated with metals), ash (a part of its content that leaches in the underground waters), etc. This pollutes air, surface water, groundwater and soil. In addition, the coal exploitation activity as raw material for power plants, excavating from mining basins, conveyor belt transport, separation before combustion and other processes involving the formation of dust sources and coal particles in the air also contribute to the pollution. Thus, it is of utmost importance to evaluate the water quality of the wells that are used as drinkable water sources by the people that live in this industrial area.
\end{abstract}

Keywords: Kosovo Energetic Corporation, wells, physicochemical parameters, heavy metals.

\section{INTRODUCTION}

The impact of various components, released as pollutants after the technological processes is undeniable. They indirectly and continuously affect the environment, human health and the living world in general [Smołka-Danielowska, 2006]. Discharged waters can enter the underground soil layers, carrying pollutants (heavy metals) that may be absorbed by the plant [Pendias et al., 2000], and then enter the food-chain, being harmful to animals and humans, [Demaku et al., 2011]. The deposited remains from the use of coal are leached by rainwater which carries the dissolved metal ions in the underground water stream. Different phenomena acting on earth that reduce the hazardous effects of pollution - to a certain extent- include the acid-base reactions with soil, precipitation, oxido-reduction, sorption and other biochemical degradation processes [Jaguś et al., 2019]. In this way, an amount of organic hazardous substances is decomposed, while heavy metals are sorbed by the soil itself. Productive land is composed approximately in $95 \%$ of inorganic matter [Mohammed, 2010]. In turn, the organic matter constitutes about 5\%. Therefore, in this case, water is most necessary for the production of vegetation (when it contains dissolved ions and other beneficial compounds), and in general for the support of the plant life [Chirenje et al., 2002]. The most important soil function is the capacity to exchange ions and essential metals in the form suitable for plant uptake [Nagajyoti et al., 2010]. Most of the groundwater originates from atmospheric waters, i.e. precipitation of water in the form of rain or snow [Fulekar et al., 2007]. If water from this source is not lost during evaporation or transpiration, it can infiltrate into the ground [Jaguś et al., 2019]. At moderate levels, the soil particles are covered with water layers, but air is still present in the pores of the soil. At higher depths, in the presence of sufficient quantities of water, it fills all the pores and gives the saturated area, the upper level of 
which represents the depth of the groundwater; therefore, the water present in the saturated area is called groundwater [Verma et al., 2017]. Because of the surface tension, the water is drawn up over the depths of the groundwater through the capillary passages [Fytianos et al., 2007]. Apart from the above-mentioned oxygen [Nagaraju et al., 2016], silicon and clay minerals, heavy metals and organic compounds that penetrate into soil and plants constitute other influential factors [Rauret, 1997]. Heavy metals can be emitted to the environment from natural and anthropogenic sources, mainly from mining and industrial thermal activity [Zhu et al., 2011]. Assessing the pollution of an ecosystem also involves the analysis of the concentrations of heavy metals in natural [Chen et al., 2017] and contaminated waters; therefore, heavy metals enter the group of dangerous non-degrading pollutants [Bradl, 2005]. The exposure to heavy metals can result in an increased risk of various neurological diseases; many studies show that most of the chemical elements constitute neurotoxins, including: $\mathrm{Hg}, \mathrm{Pb}$, As and Cd [Fulekar et al., 2007].

\section{MATERIALS AND METHOD}

In order to determine the physicochemical quality of groundwater more efficiently, the authors applied: The Council Directives and the European Parliament (98/93 / EC), [Directive. C, 98/83/EC., 2017] for waters intended to be used for human consumption and the Water Framework Directive (DKU-WFD) 2000/60, [European Parliament and of the Council., 2000], for the monitoring of the physical-chemical status of waters, directives in which groundwater.

The sampling was done in July 2018. The physicochemical analysis was performed by using the following instruments: Secom am Prim Leigh Spectrophotometer, WTW S12 Photometer, Secom am Pastel UV Spectrophotometer and other classic chemical analysis methods. The concentration of heavy metals was determined by using the ICP-OES method (at the "Agroved" Laboratory) [Canbay et al., 2016].

The sampling and the sample preparation were done according to the standard methods. The water samples were placed in plastic/ polyethylene (PVC) bottles (2L volume). The sampling was performed by placing the bottle in the opposite direction of the water flow.
Immediately, another bottle was filled and treated with nitric acid, to preserve it for the determination of heavy metals, [Kadriu et al., 2017]. At the sampling site, air and water temperature, $\mathrm{pH}$, electrical permeability, taste, color, wind and turbidity were determined. The sampling coordinates were taken using GPS and presented with the Google Maps/ Google Earth application. The sampling sites were identified as: M1-Village: Graboc (description: $30 \mathrm{~m}$ from the 30 year old landfill), M2-Village: Kuzmin (description: 4 $\mathrm{km}$ in between two old landfills) and M3-City: Fushë Kosovë (description: a city that is $1.3 \mathrm{~km}$ from the landfill).

\section{Power Plant `Kosovo`}

Although Kosovo is a small country in terms of its surface area, its subsoil is rich in energy sources and minerals. In Kosovo, about 10-12 billion tons of lignite coal was estimated to be present in two basins: in the basin of Kosovo and Dukagjini districts. The calorific value of Kosovo's coal is between 1800-2000 $\mathrm{kcal}$, and is used mainly for the production of electricity. The coal has been used since the 1960s in the villages of Mirash, the Bardhi Madh, Hade and Sibovc.

The annual production of the coal reaches around 6 million tons per year, during its processing it also releases the ashes [Igor et al., 2013], which represent the flying dust that and can potentially enter the surface waters and groundwater [Kadriu et al., 2017].

\section{RESULTS AND DISCUSSIONS}

The results of the physicochemical analysis are presented in Table 1. The obtained results were compared with the Water Framework Directive (DKU-WFD, 2000/60), [European Parliament and of the Council, 2000], and meet the criteria imposed from this directive.

Although the physicochemical parameters give some insights regarding the water quality [Szalinska et al., 2018], they do not offer the complete image regarding the water pollution [Milaim et al., 2018]. In order at least to have an idea about the inorganic contaminants, we evaluated the concentration of some heavy metals (As, Cd, Co, Cu, Fe, $\mathrm{Hg}, \mathrm{Mn}, \mathrm{Ni}, \mathrm{Pb}$, Mo, Zn). 


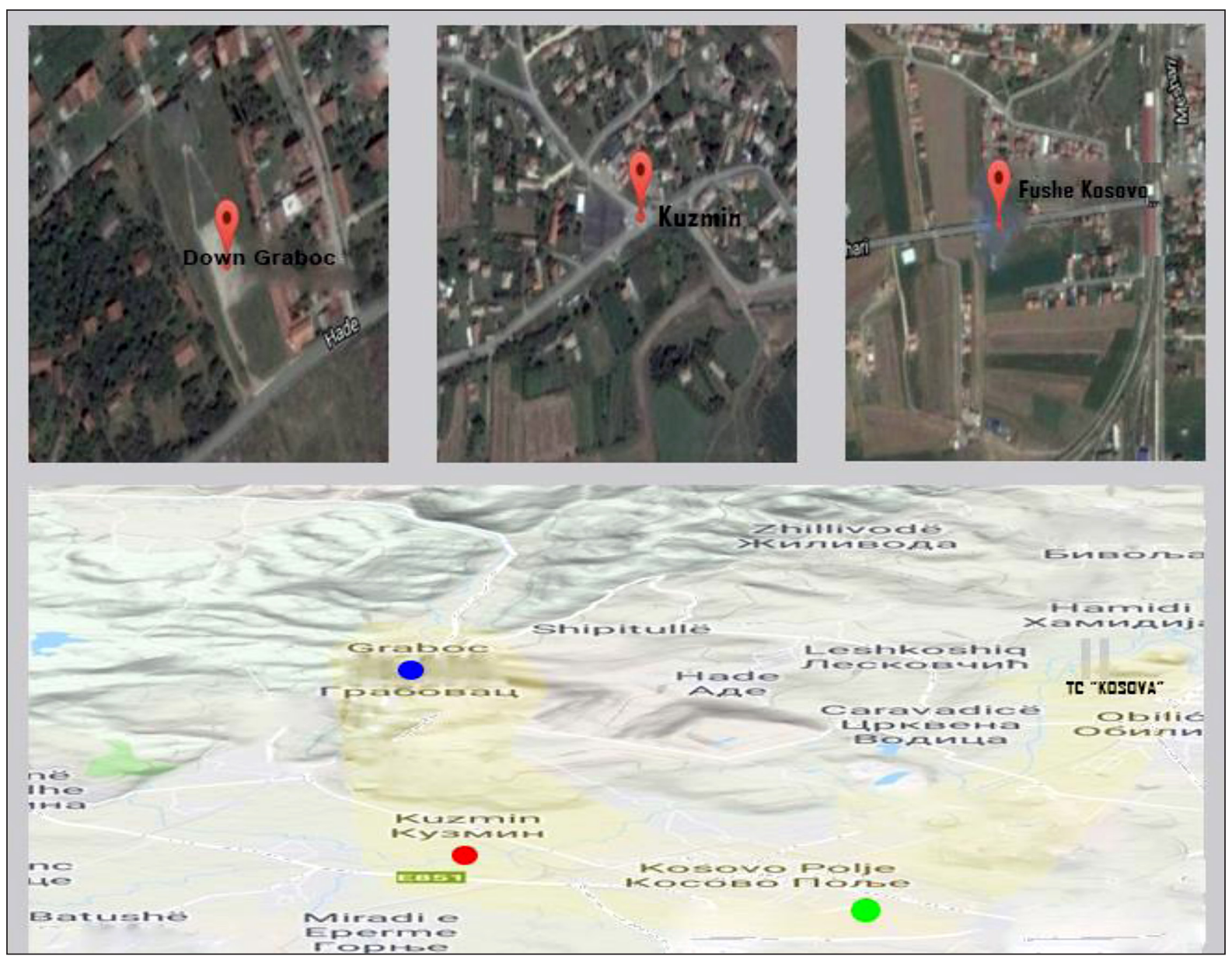

Fig. 1. Location of KEC 'Kosovo'

Heavy metals such as: $\mathrm{Cd}, \mathrm{Co}, \mathrm{Cu}, \mathrm{Hg}, \mathrm{Ni}$, $\mathrm{Pb}$ and $\mathrm{Mo}$ are below the detection limit of the ICP-OES. The results for other heavy metals are presented in the Table 2.

In order to have a better understanding regarding the heavy metal contents in between the three analyzed sampling positions, the dendogram is represented in the Figure 2. The highest similarity is found between the M2/M2 sampling positions. M1 is a distinctive sample in regard to its chemical composition.

In this context, the sample represents a possible external impact that is caused from a pollution source [Vaverková et al., 2018] that is dissimilar from the two former ones. As M1 is near the oldest landfill, this difference could have its origin from different leaching ability of heavy metal ions, imposing a different concentration profile in underground water.

The differences can be are better analyzed through the Principal Component Analysis (PCA) [Everitt et al., 1992]. On the basis of the principal component scores, PCA is able to examine multivariate relationship and explain the variance in the data while reducing the number of variables to several groups of individuals [Everitt et al., 1992]. The PCA results are presented in Figure 3 (a. the Scree plot and b. loading plot).

The differences among the four heavy metals (Figure 3a) content are explained using the first two components of the Scree plot. The PCA shows two different groups: the first group (As, $\mathrm{Mn}$ and $\mathrm{Fe}$ ) and the second one ( $\mathrm{Zn})$.

This shows that although the landfill has similar impact with regard to $\mathrm{As}, \mathrm{Mn}$ and $\mathrm{Fe}$ in all samples, the $\mathrm{Zn}$ metal might also originate from other potential sources such as: metal junkyards, which are very common in this area.

\section{CONCLUSIONS}

In this study, several heavy metals (As, Cd, $\mathrm{Co}, \mathrm{Cu}, \mathrm{Fe}, \mathrm{Hg}, \mathrm{Mn}, \mathrm{Ni}, \mathrm{Pb}, \mathrm{Mo}, \mathrm{Zn}$ ) were analyzed in the well samples with the statistical methods. From the discussions above, the authors arrived at the following conclusions. (1) The difference in the content of the metals in the moss samples in influenced by the local pollution 
Table 1. Results of physical-chemical parameters

\begin{tabular}{|c|c|c|c|}
\hline Chemical parameters & M1 & M2 & M3 \\
\hline $\mathrm{pH}$ & 7.59 & 7.30 & 7.09 \\
\hline Electrical conductivity $\left(\mu \mathrm{s} / \mathrm{cm}^{3}\right)$ & 1132 & 1702 & 1488 \\
\hline Color & transparent & transparent & transparent \\
\hline Taste & no taste & no taste & no taste \\
\hline Residue after evaporation $\left(\mathrm{mg} / \mathrm{dm}^{3}\right)$ & 747 & 1123 & 982 \\
\hline Biochemical Oxygen Demand - BOD $\left(\mathrm{mg} / \mathrm{dm}^{3}\right)$ & 1.2 & 6.3 & 2.8 \\
\hline Chemical Oxygen Demand - COD $\left(\mathrm{mg} / \mathrm{dm}^{3}\right)$ & 2.6 & 10.5 & 5.6 \\
\hline $\mathrm{KMnO}_{4}$ titration $\left(\mathrm{mg} / \mathrm{dm}^{3}\right)$ & 6.48 & 6.84 & 6.95 \\
\hline M- Alkaline MA ( mmol) & 7.50 & 10.60 & 8.20 \\
\hline Acidity $\left(\mathrm{mg} / \mathrm{dm}^{3}, \mathrm{CaCO}_{3)}\right.$ & 43 & 48 & 51 \\
\hline Chlorides $\mathrm{Cl}^{-}\left(\mathrm{mg} / \mathrm{dm}^{3}\right)$ & 23.8 & 60.4 & 59.3 \\
\hline Calcium $\mathrm{Ca}^{2+}$ (hardness, $\mathrm{dH}$ ) & 19.7 & 27.2 & 29.3 \\
\hline Magnesium $\mathrm{Mg}^{2+}$ (hardness, dH) & 9.63 & 17.8 & 10.36 \\
\hline Sulfates $\mathrm{SO}_{4}{ }^{2-}\left(\mathrm{mg} / \mathrm{dm}^{3}\right)$ & 128 & 191 & 266 \\
\hline Total hardness $\mathrm{dH}$ & 29.3 & 45.0 & 39.6 \\
\hline Bicarbonate $\mathrm{HCO}_{3}^{-}\left(\mathrm{mg} / \mathrm{dm}^{3}\right)$ & 457.5 & 646.5 & 500.2 \\
\hline Turbidity NTU & 1.8 & 3.6 & 3.9 \\
\hline Phosphates $\mathrm{PO}_{4}^{3-}\left(\mathrm{mg} / \mathrm{dm}^{3}\right)$ & 0.002 & 0.002 & 0.002 \\
\hline Ammonium ions $\left(\mathrm{NH}_{4}^{+}\right)\left(\mathrm{mg} / \mathrm{dm}^{3}\right)$ & 0.036 & 0.048 & 0.11 \\
\hline Nitrates $\left(\mathrm{NO}_{3}^{-}\right)\left(\mathrm{mg} / \mathrm{dm}^{3}\right)$ & 6.20 & 0.82 & 5.73 \\
\hline Nitrites $\left(\mathrm{NO}_{2}^{-}\right)\left(\mathrm{mg} / \mathrm{dm}^{3}\right)$ & 0.03 & 0.03 & 0.22 \\
\hline
\end{tabular}

Table 2. Concentration of heavy metals

\begin{tabular}{|c|c|c|c|c|c|c|}
\hline Elements & Unit & Method & Mean & Median & Minimum & Maximum \\
\hline As & \multirow{4}{*}{$\mathrm{mg} / 1$} & \multirow{4}{*}{$\begin{array}{l}\text { EPA 3015A } \\
\text { EPA 6010C }\end{array}$} & 0.007 & 0.01 & 0.005 & 0.01 \\
\hline $\mathrm{Fe}$ & & & 2.86 & 5.69 & 0.8 & 5.69 \\
\hline $\mathrm{Mn}$ & & & 0.00867 & 0.014 & 0.005 & 0.014 \\
\hline $\mathrm{Zn}$ & & & 0.0977 & 0.2 & 0.019 & 0.2 \\
\hline
\end{tabular}

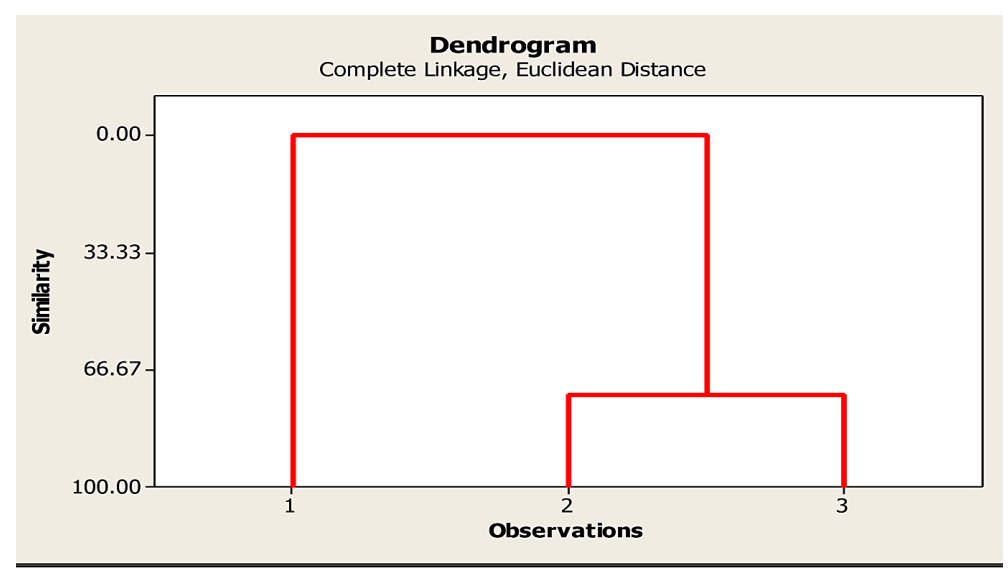

Fig. 2. Dendrogram of cluster analysis of the heavy metals in well samples for three different sampling positions

source (metal junkyards); (2) the PCA analyses show that the $\mathrm{Zn}$ metal has a distinctive source of pollution (3) the physicochemical results are in accordance with the Water Framework Directive (DKU-WFD) 2000/60.
Generally, as these wells are used from the people that live in the nearby area, we propose that local authorities should monitor these water sources periodically and also analyze these waters for possible organic contaminants. Furthermore, 

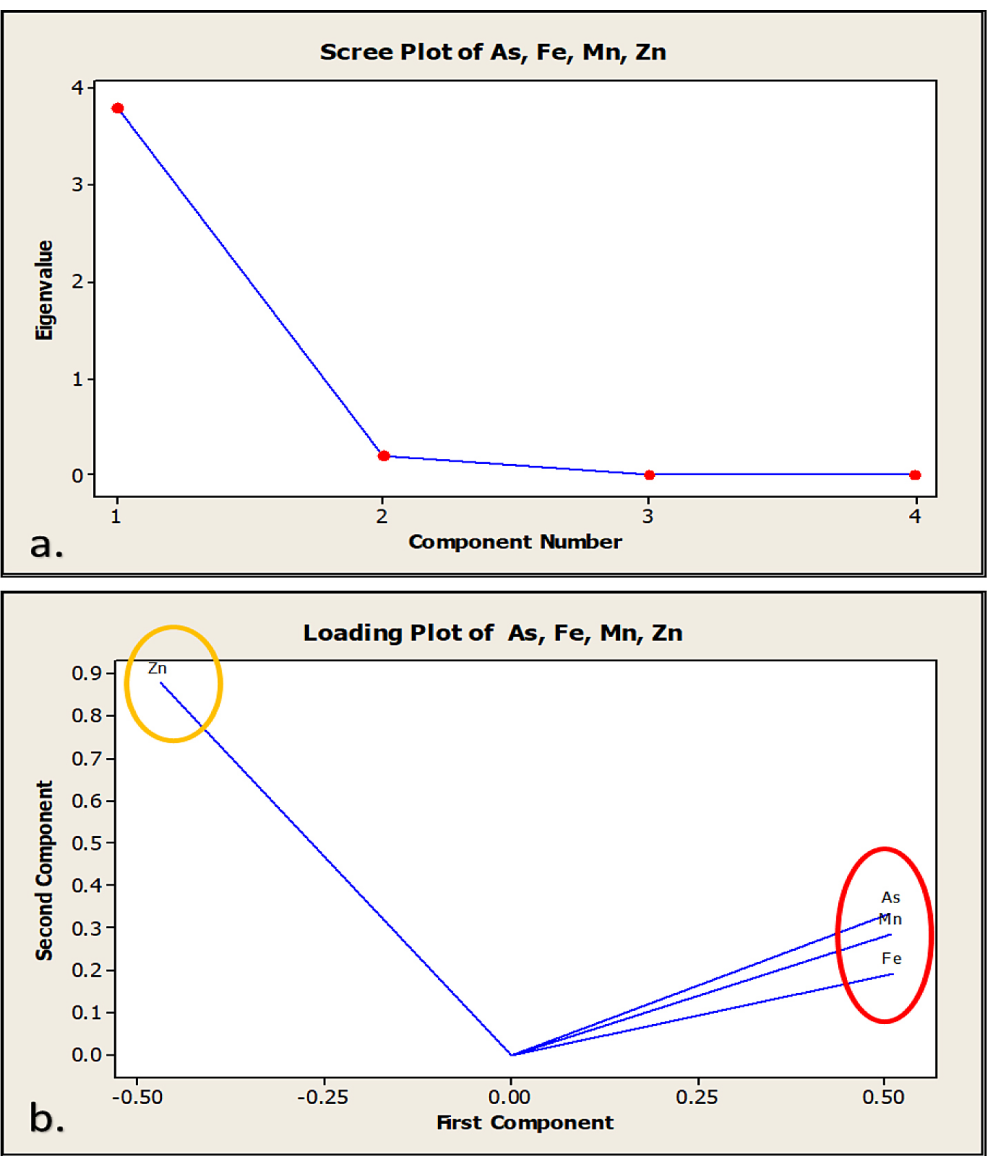

Fig. 3. Scree plot (a) and PCA coordination biplots for the analyzed heavy metals in well samples (b)

one should also analyze the pollutants in soil and the agricultural crops to have a full picture regarding the heavy metal presence in this area.

\section{REFERENCES}

1. Demaku S., Shehu I., Jusufi S., Arbneshi T., Dobra B., 2011. Heavy Metals in Coal Ash, Soil, Water and Sludge near the Two Coal-Fired Power Stations in Kosovo. J. Int. Environmental Application \& Science, Vol. 6, 412-416.

2. Kadriu S, Malollari I, Pula-Beqiri L, Aliu M, Sadiku M, Baruti B, Kelmendi M., 2017. Presence of heavy metals in water and sediment of rivers Trepça and Sitnica. Journal of Environmental Protection and Ecology 18(1), 10-21, Water Pollution.

3. Smołka-Danielowska S., 2006. Heavy Metals in Fly Ash from a Coal-Fired Power Station in Poland. University of Silesia, Faculty of Earth Sciences, ul. Będzińska 60, 41-200 Sosnowiec, Poland. Polish J. of Environ. Stud., 15(6), 943-946.

4. Jaguś A., Skrzypiec M., 2019. Toxic Elements in Mountain Soils (Little Beskids, Polish Carpathians). Journal of Ecological Engineering, 20(1), 197-202.
5. Verma Ch, Madan S, Hussein A., 2017. Heavy metal contamination of groundwater due to fly ash disposal of coal-fired thermal power plant, Parichha, Jhansi, India. Cogent Engineering, 3: 1179243.

6. Fulekar M.H, Naik D.S, Dave J.M., 2007. Heavy metals in Indian coals and corresponding fly ash and their relationship with particulate size. International Journal of Environmental Studies, 21, 2, 179-182, DOI: 10.1080/00207238308710074.

7. Bodík I., Kubaská M., 2013. Energy and Sustainability of Operation of a wastewater treatment plant. Environment Protection Engineering, 39(2). DOI: 10.5277/EPE130202.

8. Nagaraju A., Balaji E., Thejaswi A., 2016. Hydrogeochemical evaluation of groundwater in certain parts of vinukonda area, Guntur district, Andhra Pradesh, South India. Fresenius Enverionmental Bulletin, 25(5), 1520-1533.

9. Rauret G., 1997. Extraction procedures for the determination of heavy metals in contaminated soil and sediment. Talanta, 46, 449-455.

10. Fytianos K, Tsaniklidi. B, Voudrias. E., 1998. Leachability of heavy metals in Greek fly ash from coal Combustion. Pergamon. Environment International, 24(4), 477-486.

11. Szalinska E., Dobyrn K., 2018. Long-term changes 
in surface and groundwater quality in the area of a municipal landfill (Barycz, Poland). Environment Protection Engineering, 44(1), DOI: 10.5277/ epe180108.

12. Fulekar M.H, Dave J.M., 2007. Release and behavior of $\mathrm{Cr}, \mathrm{Mn}, \mathrm{Ni}$ and $\mathrm{Pb}$ in a fly ash/soil/water environment: column experiment. International Journal of Environmental Studies, 38(4), 281-296.

13. Musliu M., Bilalli A., Durmishi B., Ismaili M., Ibrahimi H., 2018. Water Quality Assessment of the Morava e Binçës River Based on the Physicochemical Parameters and Water Quality Index. Journal of Ecological Engineering, 19(6), 104-112.

14. Nagajyoti P.C, Lee K.D, Sreekanth T.V.M., 2010. Heavy metals, occurrence and toxicity for plants: a review. Environ Chem Lett. 8, 199-216. DOI 10.1007/s10311-010-0297-8.Springer-Verlag.

15. Chirenje T., Rivero.C., Ma. L.Q., 2002. Leachability of $\mathrm{Cu}$ and $\mathrm{Ni}$ in wood ash-amended soil as impacted by humic and fulvic acid. The Global Journal of Soil Science. Geoderma 108, 31-47.

16. Vaverková M.D., Adamcová D., Zloch J., Radziemska M., Berg A.B., Voběrková S., Maxianová A., 2018. Impact of Municipal Solid Waste Landfill on Environment - A Case Study. Journal of Ecological Engineering, 19(4), 55-68.

17. Zhu R, Wu M, Yang J. 2011. Mobilities and leach abilities of heavy metals in sludge with humus soil. Journal of Environmental Sciences, 23(2), 247-254.

18. Canbay H.S., Doğantürk M., 2016. Metals determination by Microwave digestion ICP-OES of some dietary supplements and diet products in Turkey. Open Access Eurasian Journal of Analytical Chemistry, 45-50.

19. Drinking Water Parameter Cooperation Project., 2017. Support to the revision of Annex i Council Directive 98/83/EC on the Quality of Water Intended for Human Consumption (Drinking Water Directive). Bonn, 11 September.

20. Bradl H.B., 2005. Heavy Metals in the Environment. Interface science and technology - volume 6. University of Applied Sciences Trier Neubrucke, Germany. Elsevier academic press: Amsterdam - Boston - Heidelberg - London - New York - Oxford - Paris San Diego - San Francisco - Singapore - Sydney - Tokyo.

21. Chen J.P, Wang L.K, Wang M.H.S, Hung Y.T, Shammas N.K., 2017. Remediation of heavy metals in the environment. CRC Press Taylor \& Francis Group 6000 Broken Sound Parkway NW, Suite 300 Boca Raton, FL 33487-2742.

22. Pendias A.K, Pendias H., 2000. Trace Elements in Soils and Plants, third edition, Pulawy, Warsaw, Poland, Unite 13.

23. Everitt B.S. and G. Dunn., 1992. Applied multivariate data analysis. Oxford University Press, New York.

24. Directive 2000/60/EC, 2000. Of the European Parliament and of the Council, of 23 October, establishing a framework for Community action in the field of water policy. 